\title{
NOS PASSOS DA PAIXÃO, O ENCONTRO DE MATRIZES: CATOLICISMO E AFRORRELIGIOSIDADE NA SEXTA-FEIRA SANTA DE BELÉM/PA
}

\section{IN THE PASSION STEPS, THE MATRIX MEETING: CATHOLICISM AND AFRO-RELIGIOSITY ON GOOD FRIDAY IN BELÉM/PA}

\author{
EN LOS PASOS DE LA PASIÓN, EL ENCUENTRO DE MATRICES: \\ CATOLICISMO Y AFRORELIGIOSIDAD EM VIERNES SANTO EM BELÉM/PA
}

\begin{abstract}
Resumo
Esse artigo analisa a ressignificação de rituais católicos referentes a Semana Santa, em especial os da Sexta-feira, feita por afro-religiosos do Tambor de Mina que rememoram e ritualizam o sacrifício, a paixão e morte de Jesus. Foram observados os rituais da Procissão do Senhor dos Passos, de Nossa Senhora das Dores e do Encontro e a Peregrinação de visita às sete igrejas por concentrarem numerosa presença destes afro-religiosos, ocupando igual espaço com os católicos. Além da pesquisa bibliográfica, utilizou-se a pesquisa de campo, de caráter etnográfico para assegurar a descrição densa dos fatos e do comportamento social. Foi utilizada ainda a técnica de entrevista como condicionante para se adquirir informações não obtidas durante a observação. O exercício de análise está sustentado nas abordagens sobre o sincretismo religioso enquanto processo de convergência entre matrizes religiosas. E na compreensão do sacrifício enquanto ato de interação entre humano e divino. À guisa de conclusão aponto que corpo, sacrifício e morte são os elementos de convergência entre as teologias afro-religiosa e católica, assimilados e reinterpretados em terreiros de Tambor de Mina, considerando mitologia e tempo litúrgico. Essa convergência possibilita que as divindades Jesus e Oxalá "compartilhem" do mesmo tempo e espaço ritual.
\end{abstract}

Palavras-chave: Afro-religiosidade. Catolicismo. Sacrifício. Morte. Sexta-Feira Santa. Sincretismo.

\section{Summary}

This article analyzes the reframing of Catholic rituals referring to Holy Week, especially those on Friday, performed by Afro-religious from the Tambor de Mina who recall and ritualize Jesus' sacrifice, passion and death. The rituals of the Procession of Senhor dos Passos, Nossa Senhora das Dores and the Encounter and the Pilgrimage visit to the seven churches were observed as they concentrated the presence of these Afroreligious, occupying an equal space with Catholics. In addition to bibliographic research, field research, of an ethnographic character, was used to ensure a dense description of facts and social behavior. The interview technique was also used as a condition to acquire information not obtained during the observation. The analysis exercise is based on approaches to religious syncretism as a process of convergence between religious matrices. And in the understanding of sacrifice as an act of interaction between human and divine. As a conclusion, I point out that body, sacrifice and death are the elements of convergence between Afroreligious and Catholic theologies, assimilated and reinterpreted in Tambor de Mina terreiros, considering

\footnotetext{
${ }^{1}$ Mestre em Ciências da Religião pelo Programa de Pós-Graduação em Ciências da Religião da Universidade do Estado do Pará, membro do Grupo de Estudo de Religiões de Matriz Africana na Amazônia (GERMAA). E-mail: jusceliocol@yahoo.com.br
} 
mythology and liturgical time. This convergence allows the deities Jesus and Oxalá to "share" the same time and ritual space.

Keywords: Afro-religiousness, Catholicism, Sacrifice, Death, Good Friday, Syncretism.

\section{Resumen}

Este artículo analiza la reformulación de los rituales católicos referidos a la Semana Santa, especialmente los del viernes, realizados por afroreligiosos del Tambor de Mina que recuerdan y ritualizan el sacrificio, la pasión y la muerte de Jesús. Se observaron los rituales de la Procesión del Senhor dos Passos, Nossa Senhora das Dores y el Encuentro y la Visita de Romería a las siete iglesias que concentraban la presencia de estos afro-religiosos, ocupando un espacio igual al de los católicos. Además de la investigación bibliográfica, se utilizó la investigación de campo, de carácter etnográfico, para asegurar una descripción densa de los hechos y el comportamiento social. La técnica de la entrevista también se utilizó como condición para adquirir información no obtenida durante la observación. El ejercicio de análisis se basa en aproximaciones al sincretismo religioso como proceso de convergencia entre matrices religiosas. $Y$ en la comprensión del sacrificio como acto de interacción entre lo humano y lo divino. Como conclusión, señalo que cuerpo, sacrificio y muerte son los elementos de convergencia entre las teologías afroreligiosa y católica, asimiladas y reinterpretadas en Tambor de Mina terreiros, considerando la mitología y el tiempo litúrgico. Esta convergencia permite que las deidades Jesús y Oxalá “compartan” el mismo tiempo y espacio ritual.

Palabras clave: Afroreligiosidad, Catolicismo, Sacrificio, Muerte, Viernes Santo, Sincretismo.

\section{INTRODUÇÃO}

Em relação a este trabalho, a primeira coisa a se dizer é que ele não é uma novidade nos estudos africanistas sobre as interações entre catolicismo e religiões afro-brasileiras na Amazônia, em especial no Estado do Pará. A antropóloga Anaiza Vergolino-Henry, em 1987 publicava o artigo "A Semana Santa nos Terreiros: um Estudo do Sincretismo Religioso em Belém do Pará”, para apresentar sua pesquisa em que a partir do conceito de sincretismo, buscou conhecer e entender os sentidos dos rituais da Semana Santa, realizados no interior das casas de culto da matriz afro-religiosa Tambor de Mina. Sua pesquisa tornou-se mola propulsora para muitas outras que encontraram no chão afro-religioso vasto campo para pesquisas científicas.

O encontro com esse campo deu-se no período de formação (Graduação e Pós-graduação) em Ciências da Religião ${ }^{2}$ e com o ingresso no Grupo de Estudos de Religião de Matriz Africana na Amazônia. Chamava atenção as semelhanças entre ritos, símbolos e liturgias que sedimentam as matrizes afro-religiosas e os do catolicismo, especialmente o advindo das expressões da religiosidade popular/rural explanadas nas pesquisas de Maués (1995) em sintonia com as de Brandão (1981) e Steil (1996), que refletem a relação entre catolicismo romano e popular, indicando o popular como uma ressignificação do romano.

As pesquisas destes autores permitem analisar as relações existentes entre as matrizes católica e afro-religiosa, compreendendo-as como um movimento recíproco e de alternâncias entre culturas que se

\footnotetext{
${ }^{2}$ Cursos oferecidos pela Universidade do Estado do Pará (UEPA) desde 2010 


\section{Nos passos da paixão, o encontro de matrizes: \\ Catolicismo e afrorreligiosidade na sexta-feira santa de Belém}

movem ora de cima para baixo, ora na direção oposta, possibilitando circularidade entre si. Laura de Mello e Souza (1986) também já reflete sobre como as interações entre habitantes nativos, africanos e missionários católicos ocorridas no Brasil, configuraram um ethos que possibilitou o encontro e convergência de teologias diferentes, que ao se fundirem constituíram uma religiosidade plural onde sagrado e profano formam um "todo absolutamente específico e simultaneamente multifacetado" (SOUZA 1986, p. 88).

Pelo fato dessa convergência poder ser pesquisada e analisada de diferentes formas, períodos e contextos, demarca-se aqui os rituais religiosos públicos que ocorrem na manhã da Sexta-feira Santa em Belém/PA, a saber: as procissões do Senhor dos Passos, de Nossa Senhora das Dores e do Encontro e da Peregrinação de visita às sete igrejas, como exemplo do amálgama religioso ocorridos na região amazônica.

Elege-se como objeto a ser observado os afro-religiosos do Tambor de Mina que participam destes rituais, buscando identificar interações e entender o processo de sincretismo ocorrido entre as duas matrizes em voga.

Salienta-se que a temática abordada neste artigo, enquanto revisita à pesquisa feita pela antropóloga Anaiza Vergolino não se configura como uma atualização de dados, mas como uma complementação, dada a novidade do "olhar": Enquanto a pesquisadora prioriza os rituais internos de terreiros do Tambor de Mina, se prioriza aqui observar a participação destes em rituais externos, ou seja de fora dos terreiros.

Metodologicamente se usou a pesquisa de campo sustentada no método etnográfico desenvolvido por Geertz (2008), entendendo que, a partir da descrição densa não se teria somente registros e anotações, mas percepções, argumentações e materiais que possibilitariam mais que analisar a descrição ritual, compreender a organização social que os criou. Segundo Geertz $(2008$, p.9) a ciência do antropólogo deve ser interpretativa, buscando ler as expressões sociais, onde o êxito do trabalho "depende tão somente das qualidades de observação, da sensibilidade ao outro, do conhecimento sobre o contexto estudado e da inteligência científica do etnógrafo".

Se utilizou ainda o método de entrevista proposto por Roberto Cardoso de Oliveira (2000) que aponta como "condicionante" do fazer antropológico o olhar, o ouvir e o escrever, meios pelos quais o pesquisador pode obter informações que não foram alcançadas na descrição densa, sendo justamente as explicações dadas pelos próprios investigados que permitirão o acesso à "matéria-prima". "Tais explicações nativas só poderiam ser obtidas por meio da entrevista, portanto, de um ouvir todo especial, de se saber ouvir" (OLIVEIRA 2000, p.22).

Dado que um elemento comum no trabalho de campo é a imprevisibilidade ou mesmo a diversidade de informações, foi empregada a observação participante para adentrar no ambiente e convívio das matrizes religiosas pesquisadas. À luz do modelo proposto por Malinowski (1984) que sugere que num levantamento de dados o proceder deve ser feito com eficácia, de forma a garantir não apenas a apresentação do "esqueleto", mas que se inclua nele "carne" e "sangue". Para tal é preciso alcançar o cotidiano da cultura 
pesquisada para melhor entender o campo, aprendendo que muitas respostas vêm com a capacidade de observar o não dito.

Sobre sua apresentação textual, este artigo está dividido em três seções: a primeira, Peregrinação e Devoção à Paixão na História, apresenta elementos conceituais e históricos desta prática milenar de deslocamento humano, movido ou não por sentimentos religiosos, que gerou o fenômeno da peregrinação e influenciou o cristianismo católico. Situa como o peregrinar como rememoração da Paixão de Cristo se expandiu pelo mundo e se ressignificando ao longo da história, inclusive no Brasil, dede o processo de colonização. Ao final, aponta os rituais e práticas devocionais que ocorrem na Sexta-feira Santa em Belém/PA como traços que se misturaram “[...] tecendo uma religião sincrética" (SOUZA 1986 p. 97).

Na segunda seção Os Passos da Paixão nas Ruas de Belém: o caminhar como oração descreve o costume de caminhar para refazer e relembrar a jornada de Jesus até a cruz, e como este, desde os tempos bíblicos até os dias atuais, tornou-se uma devoção quase universal difundida pelo estímulo às emoções relacionadas aos sofrimentos e dores humanas. Apresenta as narrativas bíblicas nos quais os rituais que ocorrem na Sexta-feira Santa estão sedimentados e aponta que em Belém eles adquiriram significados que ultrapassam a representação bíblica.

Já a terceira seção, Revivendo a Morte de Cristo: corpo e sacrifício na comunhão afro e católica, apresenta quais motivações, sentidos e significados e reinterpretações, católicos e principalmente afro-religiosos mineiros fazem da Paixão de Cristo. Descreve como a partir desses rituais públicos os adeptos das duas matrizes vivenciam em si mesmos a dimensão sacrificial como forma de aproximação com a divindade e reflete sobre como as interações, as convergências e as ressignificações entre as duas matrizes apontam para uma liturgia afrocatólica da Paixão de Cristo.

\section{PEREGRINAÇÃO E DEVOÇÃO À PAIXÃO NA HISTÓRIA}

A peregrinação de origem latina per agros ('pelos campos') está relacionada ao ato de realizar uma jornada individual ou coletiva, de um determinado espaço para outro, como demarcação de um espaço/tempo tido como sagrado. O ser humano sempre se deslocou em busca de novos espaços, não somente para sua sobrevivência, mas para dar sentido à sua existência. Se tornou homo viator por se ver forçado a migrar devido causas naturais diversas, e porque em determinadas circunstâncias saía em busca de lugares que considerava extraordinário ou sagrado (DWORAK 2017). Enquanto fenômeno antropológico, estão presentes em todas as civilizações, como afirmam Rosendahl (2002, p. 11) ao dizer que elas "constituem um fenômeno notável, comum à maioria das religiões, inserindo-se assim em diferentes contextos culturais" e Gil Filho (2008, p. 134) ao pontuar que o ato de peregrinar representa uma ruptura do cotidiano profano do homem religioso, com o propósito de integrá-lo ao devir sagrado. 


\section{Nos passos da paixão, o encontro de matrizes: \\ Catolicismo e afrorreligiosidade na sexta-feira santa de Belém}

Segundo Carneiro (2004, p. 77) as peregrinações não constituem um símbolo característico do culto cristão, muito menos uma especificidade da religiosidade ocidental, ao contrário, em muitas religiões elas foram estimuladas pela simbologia dos caminhos e pela atração por lugares sacralizados. O ato de sair em peregrinação é uma prática que ocorre desde as religiões do antigo Egito, Pérsia, Mitraísmo helênico e Zoroastras, até a Índia, China e Japão, acreditando-se que por ela se estabelece uma relação especial entre o que é terrenal e o que é sagrado. O esforço físico gasto para se chegar a um fim determinado, metaforiza a viagem espiritual que o ser humano faz para alcançar a renovação do espírito ou a salvação eterna, conforme a crença da qual se é adepto.

França (2017, p.9) aponta que os que praticavam a peregrinação, faziam-na "movidos pela devoção

religiosa [...], em busca de compreender sua própria existência e o seu papel no grande plano do qual estavam convencidos de que faziam parte: o divino". Santos (2000) destaca que a história das peregrinações se confunde com a própria história das crenças religiosas desde os tempos remotos, onde a crença em seres divinos possuidores de poderes sobre determinados locais ou aspectos específicos da vida era elemento constitutivo da cultura. Essa crença fazia com que a pessoa que se encontrava longe do local protegido por sua divindade, sempre que se percebia necessitada de seu auxílio, peregrinasse de volta a este local para buscá-lo (SANTOS 2000, p. 39).

No caso das peregrinações cristãs há duas narrativas de sentido: num primeiro momento tinha caráter de exílio voluntário motivado exclusivamente por devoção. Após o século XI tomou também forma de penitência muitas vezes imposta pela igreja como punição pública aos tidos como pecadores merecedores dessa sentença (ZUMTHOR 1994). Ambas eram vistas como ascese que comprometia o praticante a sair de sua terra natal, "trocando a segurança e o conforto do lar, seu espaço homogêneo e conhecido, pela heterogeneidade do espaço desconhecido, tornando-se ao mesmo tempo em estrangeiro e desvalido" (ZUMTHOR 1994, p. 178).

Importantes relatos marcaram e definiram as peregrinações cristãs como ato heroico. A Histânica Erétria foi uma peregrinação incentivada pelo imperador romano Teodósio I com o objetivo de se obter conselhos, bênçãos e curas e que apontava o Egito, a Síria e Jerusalém como destinos preferidos. Há as declarações de Teodoreto de Ciro (séc. IV) que, segundo Dworak (2017), apontava os lugares de martírio como locais de culto, milagres e curas, para onde os cristãos deveriam ir em peregrinação.

Coelho (2011 p. 351) afirma que "as peregrinações ganham força após o fim da perseguição aos cristãos, [...] a partir do Edito de Milão (313) e da profissão de fé do Concílio de Niceia (325)", possibilitando a convergência de três mundos: o romano, o germânico e o cristão e permitindo despontar experiências para o local onde Jesus viveu, de forma que, segundo França (2017, p.12), peregrinos procedentes da sociedade romana ou romanizada e que foi cristianizada, partiam em busca de materializar sua fé nas pegadas de Cristo, dos profetas e dos apóstolos. 


\section{Nos passos da paixão, o encontro de matrizes: \\ Catolicismo e afrorreligiosidade na sexta-feira santa de Belém}

Conforme Carneiro (2004, p.78), as peregrinações cristãs possuíam duas origens: "uma, a veneração aos lugares santos, ou seja, aqueles em que o salvador santificou com sua presença; a outra, o culto dos santos e de suas relíquias". E elas adquiriram significativa importância na história religiosa da Idade Média, por ser um processo que mobilizou milhares de pessoas, tornando-se uma das principais características desse tempo. Intrinsicamente ligadas à experiência de fé de uma pessoa ou grupo, elas foram responsáveis pelo surgimento de abadias, conventos, romarias, etc. e pela propagação do cristianismo.

A expansão do cristianismo amplamente estimulada no processo de colonização pelas Coroas portuguesa e espanhola, fincou raízes pelas Américas, e chegou o Brasil sob a tutela dos Jesuítas que tinham exclusividade na evangelização das terras conquistadas (GUMIEIRO 2013, p. 63) utilizando-a como instrumento para a dominação dos povos indígenas ${ }^{3}$. Dentre as devoções trazidas pelos jesuítas, a peregrinação e as procissões foram as mais difundidas. Eram devoções, sobretudo, de um catolicismo piedoso e santoral, expresso nos exercícios de piedade individual, intermediado pela valorização de aspectos visíveis da fé, a partir de cerimônias públicas dos sacramentos, romarias e procissões cheias de alegorias, com participação massiva do povo (JURKEVICS 2006, p. 199).

O catolicismo praticado no Brasil colonial, segundo Mattoso (1992), era amplamente popular e abarcava as dimensões cotidianas da vida. Esse catolicismo colaborou para o surgimento da devoção pela qual o culto à paixão seria praticado e, sua ritualização durante a semana santa, constituía a maneira pela qual o fiel buscava se aproximar e participar da graça divina e acalmar a consciência.

$\mathrm{Na}$ diversidade de contextos, as peregrinações apresentam algo em comum: o costume humano de se caminhar e se deslocar percorrendo determinada distância rumo a um local ou centro de poder sagrado onde se busca de modo especial, graças e favores espirituais. Meslin $(2014$, p.188) pondera que peregrinar é antes de qualquer coisa, o ato voluntário de conhecer-se pela prática desafiante do se pôr na estrada, de modo que, "[...] seja qual for a maneira como esta é feita, [...] torna-se para o peregrino a experiência dos seus próprios limites, do domínio sobre os seus sofrimentos, que ele aceitou voluntariamente desde o início”. No ato de peregrinar, para Ries (2012, p. 634), "há uma estrutura essencial: um peregrino que caminha; um lugar de chegada escolhido em razão da sua relação com o sagrado; e a motivação do peregrino que procura um encontro com o mistério e o invisível". Segundo Terrin (2004, p. 374), "O peregrino é um buscador, um penitente, $[\ldots .$.$] e por isso sabe aceitar os sofrimentos para poder chegar àquele lugar ou àquele não-lugar que$ constitui para ele um ponto de chegada, o ponto de 'saturação do sagrado', capaz de transformá-lo interiormente".

As peregrinações continuam a revelar-se como prática religiosa da busca do ser humano pelo encontro com o divino. São formas de demarcação do tempo sagrado em meio ao cotidiano, ainda que em

\footnotetext{
${ }^{3} \mathrm{O}$ uso da música, da festa e das procissões como mecanismo para atrair a atenção dos indígenas pelos Jesuítas, pode ser encontrado na "Narrativa epistolar de uma viagem e Missão Jesuítica" do Padre Fernão Cadim (Lisboa: Imprensa Nacional, 1847, pp. 58 e 59).
} 
cidades grandes e modernas. No Brasil, mesmo com suas dimensões continentais e com sua rica diversidade religiosa, existem muitas tradições de peregrinações e romarias.

No estado do Pará a tradição do peregrinar se funde com a prática das romarias e das procissões, como as Marujadas da região bragantina do nordeste paraense, os Círios existentes na maioria dos municípios, e o Círio de Nazaré, que ocorre no segundo domingo de outubro em Belém e reúne mais de dois milhões de pessoas em uma procissão que rememora a narrativa do achado da imagem de Nossa Senhora de Nazaré pelo caboclo Plácido. Ramos (2015, p. 17) em sua dissertação de mestrado apresenta esse "mito do achado":

O mito conta que ao encontrar a imagem da Virgem de Nazaré às margens de um igarapé, Plácido a levou para sua cabana, percebendo que no dia seguinte, ela desaparecera, encontrando-a novamente no mesmo lugar em que fora achada no dia anterior. Este fato inusitado aconteceu por vários dias e, até que o governador, para desvendar o mistério, mandou trancar a imagem no palácio do governo, vigiada por soldados, o que não impediu que a santa retornasse ao lugar onde fora encontrada por Plácido. Logo, percebeu-se que a "vontade" da santa era permanecer naquele lugar onde se construiu uma capela para abrigar a imagem. A notícia espalhou-se, o que chamou a atenção de grande quantidade de pessoas, curiosos e devotos. Não demorou notícias de milagres alcançados por interseção da Virgem de Nazaré. Tais acontecimentos deram origem ao Círio de Nazaré [...].

Este evento é considerado a maior procissão religiosa do Brasil, lotando as ruas da capital paraense e sendo vivido com intensidade muitos dias antes. São realizadas procissões, orações nas casas, missas e outras celebrações litúrgicas, muitas peregrinações familiares e outras 14 romarias em preparação ao grande dia.

O foco deste artigo são as procissões com grande mobilização popular que ocorrem na manhã de Sexta-Feira Santa em Belém/PA, a saber: as procissões do Senhor dos Passos e de Nossa Senhora das Dores, que se fundem numa procissão chamada de Procissão do Encontro e a Peregrinação de visita às sete igrejas. Nesse dia, pelo período da manhã, peregrinos, devotos e romeiros transitam pelas ruas do centro da cidade ${ }^{4}$ tendo no Centro Histórico de Belém ${ }^{5}$ o maior fluxo de pessoas - para acompanharem essas procissões e visitarem as igrejas antigas localizadas nesta região e que expõem para a veneração e visitação as imagens do Senhor Morto e de Nossa Senhora das Dores. Essa tradição antiga em Belém existe desde o século XVIII e se tornou importante no calendário religioso tanto dos adeptos do catolicismo, quanto da matriz religiosa afro-brasileira.

Os rituais religiosos da Sexta-Feira Santa são comuns na maioria das cidades brasileiras, entretanto isso não significa que eles tenham a mesma estrutura e formatação, ao contrário, cada um possui sua especificidade. São estruturas rituais diversas que, considerando ressignificações, influências, fatores ou preferências locais comporão o atraente mosaico da religiosidade popular brasileira, que entrelaça elementos do catolicismo com elementos das religiosidades indígenas e afro-brasileiras. Vejamos na seção seguinte os

\footnotetext{
${ }^{4}$ Refere-se às igrejas localizadas nos bairros Nazaré, Reduto, Campina e Cidade Velha

${ }^{5}$ Refere-se às igrejas localizadas nos bairros Campina e Cidade Velha 
rituais públicos que ocorrem em Belém, a capital paraense e uma das maiores cidades da região amazônica com uma população de mais de um milhão de habitantes

\section{OS PASSOS DA PAIXÃO NAS RUAS DE BELÉM: O CAMINHAR COMO ORAÇÃO}

Desde o século IV d.C. tornou-se costume caminhar como forma de relembrar a jornada de Jesus até a cruz, passando essa prática a ser chamada Via Crucis ("caminho do sofrimento") ou "Via Sacra" e tornando a Sexta-feira Santa o dia mais sagrado para o cristianismo católico. Seu calendário litúrgico a demarcou como dia Santo", único do ano em que a missa não é celebrada, ao contrário, se realiza a Ação Litúrgica da Paixão para relembrar os momentos ocorridos com Jesus até sua morte e sepultamento. Essa liturgia se encerra em silêncio e que dever ser mantido até a noite do Sábado.

Para Eliade (1992), todo ritual, em sua essência, expressa a necessidade de se atualizar no tempo atual o drama ocorrido no tempo das origens, pois no rito se fundem o mundo imaginado e o mundo vivido. Nesse sentido, os rituais realizados na Sexta-feira Santa, são maneiras de no tempo presente, atualizar o que ocorreu com Jesus no tempo mítico em que os fiéis que deles participam acreditam estarem imitando o que foi vivido pelo próprio Jesus no tempo narrado pelos textos bíblicos.

Resgatando a narrativa bíblica, apresenta -se aqui como através de diversos rituais esse acontecimento ganhou contornos e se transformou em narrativas singulares de muitos lugares e culturas, inclusive da afro brasileira. Destaca-se que os rituais que ocorrem em Belém são formas de rememoração, para católicos e afro-religiosos, do que ocorreu com Jesus e, participando destes rituais, experimentam em si mesmos aquilo que foi vivido por ele.

Os quatro evangelhos presentes na Bíblia, em perspectivas e contextos diferentes narram a paixão, morte e ressurreição de Jesus, descrevendo que ele foi retirado do Monte das Oliveiras, onde orava, e levado primeiramente à presença de alguns sacerdotes, escribas e anciãos no sinédrio, onde foi réu de um julgamento precipitado e injusto. Sentenciando-o culpado, os sacerdotes o enviaram à Pôncio Pilatos, governador de Roma, para que confirmasse a sentença e decidisse sua condenação à crucificação, ou o libertasse. Em um primeiro momento Pilatos transfere a decisão para o Rei Herodes, que sem saber como decidir, devolve-o à Pilatos, e este, pressionado pelos sumos sacerdotes determina ao povo decidir sobre.

O povo decide pela soltura do criminoso Barrabás em troca da condenação de Jesus, e Pilatos, o entrega aos soldados para ser açoitado e novamente mostra-o ao povo, imaginando que o açoite bastaria. Foi surpreendido por gritos de condenação à crucificação. Pilatos lava as mãos e ordena que se faça a vontade da multidão.

Jesus foi obrigado a carregar uma cruz pelas ruas de Jerusalém até o calvário, onde nela foi pregado e, após horas de tortura e sofrimento, morreu em meio a dois ladrões. Nesse momento ocorreu um terremoto 


\section{Nos passos da paixão, o encontro de matrizes: \\ Catolicismo e afrorreligiosidade na sexta-feira santa de Belém}

derrubando as estruturas do templo de Jerusalém e rasgando o véu do santuário de cima a baixo. Uma escuridão toma conta do lugar, deixando a grande multidão amedrontada e consternada pela morte de Jesus ${ }^{6}$.

Ao longo do tempo essa narrativa foi sendo divulgada e foi desenvolvendo e diversificando representações deste acontecimento, de modo que reproduzi-la no período da Semana Santa tornou-se ação coletiva. Na maioria das cidades brasileiras encenar esta narrativa é tradição, umas conhecidas somente pela população local e outras nacionalmente famosas como a de Nova Jerusalém (PE), considerada o maior espetáculo ao ar livre do mundo, com um público de aproximadamente 80 mil pessoas. Em Várzea Alegre (CE), há o encontro dos penitentes para a Procissão do Fogaréu, que reúne mais de 200 penitentes nas vias públicas da cidade num cortejo onde a principal ação é a autoflagelação.

Segundo Jansen (2009), em Belém esta narrativa é relembrada a partir de muitos espetáculos teatrais, porém, a principal característica da "Paixão Belenense" é o cortejo de rua, onde as cenas são exibidas ou refletidas em vários pontos da cidade, tendo o espectador como integrante da narrativa e os textos, adaptados dos evangelhos, possuem uma diversidade da poética teatral. "As escritas, [...] amedrontam, provocam, comovem o público fiel da Paixão, apesar e para além das 'traições' ou alterações feitas à temática considerada original" (JANSEN 2009, p.6). Sejam as encenações de rua, os espetáculos organizados em teatros ou anfiteatros ou as procissões e peregrinações realizadas Brasil afora, ainda que se busque a inovação ou os recursos modernos, o cerne de tudo é a tradição de rememorar a Paixão. Na capital paraense, os rituais mais tradicionais de rememoração da Paixão de Jesus são as procissões do Senhor dos Passos, de Nossa Senhora das Dores e do Encontro e a Peregrinações de visitas às sete igrejas.

As diversas formas de rememorar a Paixão terão em suas estruturas uma, ou mais de uma das personagens presentes na narrativa, podendo ser José de Arimatéia, um dos discípulos, Nicodemos, os ladrões, Maria, Maria Madalena, Simão de Cirene, soldados etc., como mecanismo de tornar mais real a narrativa. Nas procissões que ocorrem em Belém, além das imagens do Senhor dos Passos e de Nossa Senhora das Dores, a única personagem presente é Verônica, que tem participação destacada na Procissão do Senhor dos Passos, durante sete paradas que relembram os momentos vividos por Jesus na sua "Via Crucis".

No contexto desta pesquisa, para observar estes rituais, se seguiu um planejamento que considerou horário e local do ritual a ser observado naquele ano: Em 2015 observou-se a Procissão do Senhor dos Passos desde a Basílica Santuário de Nazaré até Igreja das Mercês e, em seguida se acompanhou a Peregrinação de Visita às sete igrejas feita por um determinado grupo afro-religioso. Em 2016 foi feita a observação da procissão de Nossa Senhora das Dores desde a saída na Capela São João Batista até a Igreja das Mercês (ambas no Centro Histórico da cidade). Depois, se acompanhou um grupo afro-religioso na Peregrinação de Visita às sete igrejas.

\footnotetext{
${ }^{6}$ A narrativa da Paixão está descrita com detalhes nos evangelhos de João (18, 1 - 19, 42); Lucas (22, 14 - 23, 56); Marcos $(14,1-15,47)$ e Mateus $(27,11-54)$ 


\section{Nos passos da paixão, o encontro de matrizes: \\ Catolicismo e afrorreligiosidade na sexta-feira santa de Belém}

No ano de 2017 o foco foi o acompanhamento da Peregrinação de Visita às sete igrejas feita por um grupo afro religioso e a observação do Encontro das procissões no Largo da Igreja das Mercês, seguida da Procissão do Encontro, deste local até a Catedral da Sé. Em 2018 observou-se católicos e afro-religiosos em Peregrinação de visita às sete igrejas e no período da tarde, o ritual interno da Mesa de Oxalá no Terreiro Mina de Yemanjá, no bairro da Pedreira, periferia de Belém. Já em 2019, se observou, em movimento de alternância, as procissões e a peregrinação e à tarde o ritual interno de Obrigação da mesa de Oxalá, no Terreiro de Mina Nossa Senhora da Conceição, no bairro periférico do Entroncamento.

Os rituais que ocorrem na Sexta-feira Santa, são expressões devocionais com grande participação popular e forte intensidade dramática como forma de repetição do sofrimento de Jesus. Nestes rituais há a ideia de que o próprio Jesus caminha junto, sendo um dos momentos especiais o encontro com sua mãe, Maria, intitulada de Nossa Senhora das Dores. Na capital paraense, estes rituais constituem-se como importantes manifestações religiosas da cidade, atraindo milhares de pessoas e unindo matrizes religiosas diferentes, aproximadas pelas simbologias rituais. E pela integração dos calendários litúrgicos católico e afro-religioso, expressam a presença da uma religiosidade afro-amazônica.

É necessário ponderar que não são todas as matrizes afro-religiosas existentes na cidade de Belém que celebram rituais relacionados à Sexta-feira Santa ou participam dos que são realizados pela Igreja Católica, como é o caso do Candomblé. As que se envolvem neste dia, geralmente advêm das matrizes Umbanda e Tambor de $\mathrm{Mina}^{7}$, sendo esta última matriz foco deste trabalho. Pesquisadoras como VERGOLINO (1987) e LUCA (2010) já se debruçaram sobre a matriz Afro-religiosa Tambor de Mina para investigarem aspectos como Tempo litúrgico, ritual, panteão, simbolismo etc. Iluminado por suas pesquisas, o aspecto aqui abordado é o ritual, a partir das procissões e da peregrinação já citadas acima.

As procissões ocorrem desde a quarta-feira à noite, quando é realizada a chamada Procissão da Fuga, iniciada a partir das $19 \mathrm{~h}$ e que consiste em conduzir a imagem do Senhor dos Passos da Catedral da Sé, no Centro Histórico de Belém, até a Basílica Santuário de Nazaré, no centro da capital onde é exposta à visitação até sua saída na Procissão do Senhor dos Passos.

Realizada na manhã de Sexta-feira Santa, a Procissão do Senhor dos Passos faz alusão ao caminho de Jesus desde o Sinédrio até ao Calvário. Uma reconstituição do que ocorreu nas ruas de Jerusalém, tendo a ideia de que o próprio Cristo caminha entre os devotos carregando sua cruz nos ombros, trazendo em seu

\footnotetext{
${ }^{7}$ A religião afro-brasileira Tambor de Mina chegou em Belém em meados do século XIX, trazida pelos africanos escravizados vindos do Daomé (atual República Popular do Benim) para os estados do Maranhão e Grão-Pará. O termo Mina faz referência ao Forte São Jorge de El' Mina, maior empório de escravizados sob domínio português que se situava na Costa do Ouro, atual Gana. Este forte exportava mão-de-obra negra para diversas partes do Brasil (VERGOLINO 2003; LUCA 2010). No Estado do Maranhão, em meados do século XIX, estes negros fundaram duas casas na cidade de São Luís: a Casa das Minas - de tradição Jeje - e a Casa de Nagô - com influência da tradição Nagô. Do Maranhão, os mineiros migraram para Belém em duas etapas: a primeira composta por religiosos atraídos pela economia gomífera (fins do séc. XIX e início do XX) e a segunda constituída por paraenses que foram ao Maranhão buscar iniciação durante a década de 70 e 80 do século XX.
} 


\section{Nos passos da paixão, o encontro de matrizes: Catolicismo e afrorreligiosidade na sexta-feira santa de Belém}

corpo as marcas causadas pelo sofrimento que lhe foi imposto entre a prisão e a crucificação. O início desta procissão é sempre às $8 \mathrm{~h}$ da manhã, porém desde a madrugada já há concentração de pessoas esperando sua saída. Enquanto isso, muitas pessoas entram e saem da Basílica repetidas vezes, dentro, contemplam a imagem que, contendo expressão de sofrimento, comove muitas pessoas, sendo possível notar muitas delas em atitude de pranto ou lágrimas nos olhos, reproduzindo o comportamento de alguém que participa de um velório.

A Procissão de Nossa Senhora das Dores também ocorre nesta mesma manhã e sai da Capela de São João Batista com destino ao Largo da Igreja das Mercês, local onde encontrará a Procissão do Senhor dos Passos. Esta também se inicia às $8 \mathrm{~h}$ e é acompanhada em sua maioria por mulheres que seguem devotamente pelas ruas antigas da Cidade Velha a imagem de Maria, intitulada de Senhora das Dores. As pessoas que chegam para esta procissão costumam entrar na igreja, contemplar a imagem e, buscar um lugar próximo dela para ali ficar até o momento da saída. Outras, chegam ao local e se fixam no largo, demarcando lugar bem perto da porta por onde sairá a imagem para acompanharem o cortejo o mais próximo possível dela.

A Procissão, do Encontro, é a convergência dessas duas procissões, um momento muito esperado e que ocorre bem à frente da Igreja de Nossa Senhora das Mercês, onde, por volta das $11 \mathrm{~h}$, as imagens se aproximam em pontos opostos daquele largo e, como que num teatro ensaiado, em movimentos lentos e silenciosos, as imagens se aproximam para, durante a preleção do Sermão do Encontro, serem contempladas pelos presentes. Ao término do sermão, as duas imagens seguem juntas até a Catedral da Sé.

Paralela à essas procissões, desde as $6 \mathrm{~h}$ da manhã ocorre a Peregrinação de visita às setes igrejas, num movimento intenso de católicos e afro-religiosos que caminham sozinhos ou em grupo rumo às igrejas localizadas no Centro Histórico de Belém. Muitos caminham descalços, em silêncio, rezando, levando velas ou terços nas mãos ou moedas ou oferendas para serem depositadas nas escadarias ou laterais das igrejas. Os peregrinos vez ou outra se encontram na mesma igreja onde está ocorrendo as paradas das procissões, clareando o entendimento de que estes rituais se complementam, ainda que estejam em locais distintos ${ }^{8}$.

Os rituais são acompanhados tanto por católicos, quanto por afro-religiosos e estes últimos, geralmente estão vestidos com as vestes próprias da religião, têm no pescoço suas guias ${ }^{9}$ e na cabeça os

\footnotetext{
${ }^{8}$ Existem templos erigidos em diferentes épocas que estão nas imediações do Centro Histórico de Belém e que compõem tanto o roteiro da peregrinação, como das procissões. São eles: as capelas do Colégio Santo Antônio, do Hospital da Ordem Terceira e a Capela Pombo; as igrejas de Nossa Senhora do Rosário da Campina ou dos homens pretos, da Trindade, de Sant'Ana e do Carmo. E ainda: as igrejas de Nossa Senhora das Mercês, onde ocorre a culminância das procissões, a de Santo Alexandre e a Catedral da Sé, ponto de encerramento quer da Peregrinação, quer das procissões. Além das igrejas citadas, há ainda a Capela de Lourdes, que está na lista das que são visitadas no ritual de Peregrinação, mas que está fora do Centro Histórico de Belém.

${ }^{9}$ Guias ou Fios de conta são os colares normalmente feitos de miçangas de cor específica de acordo com o orixá, Inkice, Vodun, etc e que tem um significado específico e individual. Através delas se pode saber o grau de iniciação da pessoa e a que nação pertence. São objetos de identificação dos fiéis às suas divindades e que de acordo com o mito, a montagem, a lavagem e a entrega dos fios-de-contas constituem momentos fundamentais no ritual de iniciação de um adepto, pelo qual daí em diante, além de unido, estará protegido pelos orixás.
} 
turbantes (ojá-oris) com suas várias formas de representar ou a senioridade ou o grau de conhecimento. Também carregam ramos de planta nas mãos, havendo quem carregue sacolas contendo pratos com pães ou copos com milho branco cozido para serem depositados como oferendas. Sobre esta questão, Avancini (2010) ressalta que nas religiões afro-brasileiras, as oferendas estão ligadas à organização das sociedades e fazem parte de uma relação de troca em que uma linhagem a oferecia como tributo ou dádiva. A autora assevera: “[...] a oferenda significa uma dádiva de gratidão ao Orixá de quem o devoto espera proteção, configurando uma relação de intercâmbio e de religação entre o Orum e o Aye, entre o sagrado e o que chamamos de profano" (AVANCINI 2010, p. 140).

Segundo Hurbert (2011, p. 96), as oferendas são um procedimento rotineiro nas práticas afroreligiosas e "[...] servem como uma restituição do axé, espécie de força divina, que atua como suporte das experiências humanas: vêm dos deuses e deve ser a eles restituída". São, na verdade, trocas simbólicas entre os seres divinos e os humanos que os devotam; um "fator mediador das relações que se dão entre essas duas instâncias, serve como elemento formalizador dos vínculos" (HURBERT 2011, p. 97).

Em Belém as oferendas depositadas nestes rituais são quase sempre pão, água e milho branco cozido, representando as divindades lembradas neste dia: Jesus, para os católicos e Oxalá, para os afroreligiosos: O pão alimento oferecido por Jesus na sua última ceia, alude ao seu próprio corpo quando ele mesmo, abençoando-o e partindo-o, mostrou aos discípulos e disse "tomai; isto é o meu corpo que será dado por vós" (Evangelho de Marcos 14, 22). Para os católicos, olhar o pão é lembrar esse momento em que Jesus oferece seu corpo à morte pelo bem da humanidade. Já o milho branco (agbadô), é um grão sagrado nas religiões afro-brasileiras e significa sustento, limpeza e harmonização do Orí (cabeça). Representa a energia que apazígua, restitui a vida, cura doença e outras mazelas, elimina a pobreza e a fraqueza e devolve o ânimo, tal qual a função do orixá Oxalá, a quem ele é oferecido. A oferenda deste alimento para Oxalá tem a função de restituir e redistribuir o axé.

A água é um elemento presente em rituais de todas as religiões e no caso desses, está relacionada às crenças da religiosidade popular em que depositar copos com água em portas e escadarias de igreja ou capelas, nos portões e sepulturas dos cemitérios ou nas janelas e portas do fundo das casas, tem o sentido de "matar a sede" das almas que estão no purgatório e aliviá-las no sofrimento de purgarem uma espera eterna. Ao oferecê-la para estas almas, acredita-se que elas em retribuição não perturbarão quem a ofereceu e nem seus entes, protegendo-os dos espíritos ruins.

Os ramos de plantas, levados nas mãos por alguns afro-religiosos evidenciam sua importância e utilização nesta religião. Para Santos e Gonçalves (2011), este elemento é compreendido como um veículo de axé, sendo utilizado para lavar e sacralizar objetos rituais, purificar a cabeça e o corpo, curar doenças e afastar males de todas as origens. Na Sexta-feira Santa usa-se especificamente o ramo da arruda por ser uma planta votiva do orixá Oxalá, energia da criação revestida da pureza e da ética. A compreensão é que esta 
planta posta em um ambiente hostil e pesado, para limpá-lo toma sobre si as energias negativas existentes, ao ponto de murchar e morrer em consequência dessa limpeza.

Esse gesto lembra tanto Oxalá e sua função de limpar, apaziguar, restituir e recriar o mundo, quanto Jesus que para salvar a humanidade, se entrega a morte, como narra um texto bíblico muito usado nesse período: "ele tomou sobre si as nossas enfermidades e as nossas dores levou sobre si; [...] ferido pelas nossas transgressões e pelas nossas iniquidades" (Livro de Isaias 53, 3-5).

Durante as procissões e a peregrinação, católicos e afro-religiosos costumam entrar nas igrejas, se ajoelharem por alguns minutos, fazerem orações silenciosas, depositarem moedas nos nichos dos santos e se dirigirem para a pia batismal, seja para uma benção com água benta, no caso dos católicos, seja para uma breve lavagem das guias, no caso dos afro-religiosos. Também costumam fazer breves orações nas portas frontais, nas paredes laterais ou nos degraus externos das igrejas. E no chão ou nos degraus, do lado de fora, costumam fazer a oferenda do pão, do milho branco cozido e da água, ou somente acender velas e depositar moedas em favor das almas dos vivos e dos mortos.

Apesar das procissões concentrarem grande número de pessoas e a peregrinação se dá num grande vai-e-vem de caminhantes, quer no interior das igrejas quer nas ruas, as atitudes que prevalecem neste dia são o silêncio, o recolhimento, a descrição e o pesar. Até as 13h, as ruas do Centro Histórico estão tomadas de gente que, rezando, acompanhando uma das procissões, peregrinando, fazendo suas oferendas, acreditam estarem dando os passos que Jesus deu e revivendo em si mesmo os seus últimos momentos. Revivem, não o tempo histórico atual, mas o tempo santificado, do eterno presente mítico (ELIADE 1992, p. 39), fundamentando inclusive, a necessidade de se realizar estes rituais até antes das "três horas da agonia" (15h), pois após esse horário não teria sentido realizá-los, uma vez que Jesus está morto.

Essa fundamentação reforça a ideia de que esses rituais são também a ritualização do evento morte e do velório - tema que será abordado na próxima seção - sendo evidente na Capela do Hospital da Ordem Terceira e na Igreja de Nossa Senhora do Rosário da Campina. Em ambas, a imagem de Jesus Cristo morto está posta em cima de uma mesa, encoberta com véu e rodeado de flores e, ao seu redor, as pessoas se aglomeram para se aproximar, olhar, tocar, beijar e depois sentaram-se para experimentarem a desolação de um luto coletivo.

Tanto os católicos quanto os afro-religiosos entrevistados durante os rituais públicos, expressam a ideia de que, ao participar deste momento, muitas vezes descalços, em jejum, privados da fala e da aproximação com os outros, é a forma que têm de não permitirem que Jesus passe por esse momento sozinho e que, ao sacrificarem-se com esses gestos, sacrificam-se igual a Jesus. Privar o corpo de qualquer conforto é ação sacrificial feita por estes indivíduos na busca de relacionarem-se com o divino.

Destarte, o trânsito entre catolicismo e afrorreligiosidade que se manifestam nesses rituais, aponta o processo de aproximação, quase nunca pacífico, entre negros, índios e portugueses, durante o período da colonização, entendido ora como processo de resistência, ora como processo de ressignificação, a qual 


\section{Nos passos da paixão, o encontro de matrizes: \\ Catolicismo e afrorreligiosidade na sexta-feira santa de Belém}

chamamos sincretismo. Segundo Ferretti (2007), este não foi apenas um fator de resistência à dominação cultural e religiosa, ao contrário, os que herdaram a religião dos antepassados africanos, tendo também que aceitar a religião imposta pelos colonizadores, ficaram com as duas, cultuando ambas com igual devoção. Ainda segundo este autor, o sincretismo não foi e nem é uma via de mão única que atinge e modifica uma expressão religiosa em detrimento de outra, ambas são modificadas (FERRETTI 2007, p. 4).

Neste sentido, para Ferretti (2007), o sincretismo nas religiões afro-brasileiras não representa um disfarce de entidades africanas em santos católicos (FERRETTI 2007, p. 55), mas uma "reinvenção de significados" e uma "circularidade de culturas", de modo que, os afro-religiosos têm plena consciência de que os elementos cristãos presentes na religião se deram num primeiro momento em um processo de imposição, mas que ao longo do tempo foram reinterpretados e ressignificados. E, no que tange especificamente à matriz afro-religiosa Tambor de Mina, uma das reinterpretações feitas por esta é que a Sexta-feira Santa é um dia de cuidado e de perigo, por isso é preciso fazer "sacrifícios" como resguardos, jejuns, interditos alimentares ${ }^{10}$, banhos de cabeça, recolhimento e silencio. Os adeptos desta matriz são orientados a não irem às ruas neste dia, a não ser que seja para cumprirem as obrigações rituais como acompanhar uma das procissões ou peregrinarem em visita às sete igrejas.

Na matriz afro-religiosa Tambor de Mina, a ideia de perigo está relacionada tanto à morte e sepultamento do corpo de Jesus, como à descida dos Orixás ao ayê, o que convoca atenção e cuidado com os espíritos que podem "perturbar" nesse tempo, por isso os afrorreligiosos estão sempre usando o contraegun ${ }^{11}$ nos braços, como comentou uma afro-religiosa que fazia a peregrinação: "tudo o que fazemos, são formas de se purificar e se proteger nesse tempo de vazio, perigoso, não só pela descida dos orixás, mas também pela morte de Jesus. Nós fazemos esse sacrifico por causa da morte de Cristo".

Torna-se evidente que as representações de temor, vazio, escuridão, morte, articuladas, relidas e ressignificadas tanto pelas tradições africanas quanto pelas práticas cristãs católicas teceram um imaginário peculiar do que seja este dia: No corpo de Jesus Cristo e na experiência de seu sacrifício e morte, o humano que o rememora torna-se divino.

\section{REVIVENDO A MORTE DE CRISTO: CORPO E SACRIFÍCIO NA COMUNHÃO AFROCATÓLICA}

A prática de realizar procissões e peregrinar na Sexta-feira Santa é uma das maneiras que se têm de reviver e ritualizar a morte de Jesus, reservando este dia para se refletir sobre seu sacrifício. Sua Paixão e

\footnotetext{
${ }^{10} \mathrm{O}$ interdito alimentar é diferente do jejum. Neste segundo há a abstinência de carne ou de alimento, enquanto que no primeiro, se resguarda de comer certas comidas que não são do agrado dos orixás, principalmente de Oxalá, o orixá lembrado nesse dia.

${ }^{11}$ Uma espécie de bracelete feito de palha e usado nos braços e que serve justamente para proteger desses espíritos desorientados que atuam para a desordem ou para a zombaria.
} 
morte é a espinha dorsal da doutrina católica que tem em sua liturgia, as 15 horas ou "Três horas da agonia" com o ápice desse dia pelo fato da narrativa bíblica indicar como o horário em que Jesus depois de todo sofrimento vivido no caminho até o calvário, expirou e morreu. Por isso, também é costume nesse horário, se procurar igrejas para rezar ou ouvir o Sermão das Sete Palavras ou da Descida da Cruz, ou mesmo assistir encenações que aludem a esse momento. Também é costume acompanhar as tradicionais procissões do Senhor morto que carrega pelas ruas um esquife com a imagem de Jesus morto, numa clara teatralização de um cortejo fúnebre.

Em muitos lugares devotos revivem este dia com expressões corporais de mortificação e sacrifício que lhes permitem se reconhecerem com o sacrifício de Jesus e de Maria, uma vez que, na religiosidade popular, esta não é inferior a ele. Quer no catolicismo oficial, quer na religiosidade popular, a Sexta-Feira Santa é para viver o silêncio, suspender as diversões e evitar os prazeres em memória ao sacrifício de Jesus.

A partir de inúmeros rituais, muitos envolvendo diretamente o corpo, fiéis buscam expressar sua devoção a Jesus que se sacrificou pela humanidade. Conhecida como devoção sacrificial ou à Paixão, segundo Pereira (2003), essa se propagou no mundo ocidental percorrendo longo caminho histórico e geográfico desde a Europa, passando pela América Latina e chegando ao Brasil através da colonização e implantando diversos santuários para este fim. Em Belém não há um santuário dedicado a esta devoção, mas como visto anteriormente, existem muitas igrejas que se tornaram centros desta devoção que atraem na Sexta-feira Santa adeptos do catolicismo e das religiões afro-brasileiras.

A ritualização do sacrifício e morte de Jesus se entrelaça nestas duas religiões pela relevância dada por ambas ao sentimento de vazio, de perda e de perigo causados pelo evento morte. Os rituais são realizados em vista de não se sair do campo do sagrado e de se manter firme ante a liminaridade representada mais pelo evento morte que pelo sacrifício de Jesus. Mauss e Hubert (2013) argumentam que o sacrifício é originalmente uma dádiva que se faz aos deuses aos quais é conveniente se ligar, e que sua função social se concentra na prática de certos rituais realizados com o objetivo de manter contato com a divindade do qual se tem necessidade. Segundo estes autores, pelo fato de o esquema do sacrifício variar de acordo com suas funções características, uma fórmula para também pensá-lo é a de que ele é um ato religioso que mediante a consagração de uma vítima modifica o estado da pessoa moral que o efetua.

Nesta pesquisa, se tem claro que a vítima simbólica é Jesus, entretanto ele não está sozinho, há os peregrinos - católicos e afro-religiosos - que participam dos rituais mortificando seus corpos como forma de entrar em comunhão com ele. Essa participação pode ser entendida como uma "dádiva" a ser ofertada para dele se alcançar a comunhão. Ferraro (1993, p. 90) pontua que os rituais relacionados à Paixão dizem respeito a uma "dimensão redentora" da vítima, neste caso os fiéis. Para eles o ato de privar o corpo de algo é o sacrifício realizado em vista de se alcançar algo mais profundo: a comunhão com o sagrado.

Fernandes (1982), resgatando a etimologia da palavra sacrifício, aponta que esta advém da expressão latina "sacra facere", compreendida pelo termo "fazer sagrado" caracterizando rituais em que 


\section{Nos passos da paixão, o encontro de matrizes: \\ Catolicismo e afrorreligiosidade na sexta-feira santa de Belém}

algo profano é ofertado, consagrado ou destruído para tornar-se sagrado "[...]por uma inversão radical de suas marcas características, implicando uma transformação substancial” (FERNANDES 1982, p. 84). Conforme Mauss e Hubert (2005, p. 25) a primeira função que o sacrifício carrega é a de conferir caráter religioso ao momento. Tudo aquilo que está no plano profano, muda para o plano sagrado.

Católicos e afro-religiosos que participam dos rituais ocorridos na capital paraense, justificam ser um compromisso de acompanharem Jesus no momento de sofrimento. Esse compromisso é a forma encontrada de identificação com ele e concretizada pelo ato de caminhar/peregrinar as vezes descalço, em jejum e privado da fala e da aproximação com os outros, ainda que se esteja em grupo. A ideia e o desejo de caminhar/peregrinar em comunhão com Jesus configuram o "in illo tempore" apontado por Eliade (1992), como o tempo em que humano e divino interagiam entre si. Estes "homos religiosus" do tempo atual, reconectam suas existências ao "divinus" a partir dos ritos (ELIADE, 1992 p. 38).

$\mathrm{O}$ ato de caminhar/peregrinar, segundo Sanchis (2006, p. 86), é um ritual caracterizado pelo sacrifício desde seu início até sua concretização com a apresentação do peregrino ao "Santo", "com quem se conversa se trocam bens, energia e saúde (promessas)", o que coaduna com o desejo dos adeptos das duas matrizes religiosas que participam dos rituais em questão: através destes, buscam aproximar-se da divindade, tornar-se parte dela, sendo seus próprios corpos o lugar do encontro.

$\mathrm{Na}$ religiosidade popular o corpo assume importante papel nos rituais por ser ele próprio receptor e emissor da presença do divino e, conforme Rodrigues (1975, p. 131), “é um complexo de símbolos e de um sistema simbólico que porta a sua mensagem, mesmo que os seus receptores e emissores não estejam ou não sejam conscientes dela e enquanto complexo de símbolos, [...] possui um caráter polissêmico". Duas situações apontam para o caráter polissêmico do corpo nos rituais da Sexta-feira Santa em Belém: uma foi a justificativa de um afro-religioso sobre sua participação na peregrinação de visita às sete igrejas ser "uma obrigação de se mortificar pelo sofrimento de Cristo que está sofrendo e é muito importante viver esse momento com respeito e de se sacrificar como ele" (L.A. Integrante do Terreiro Tambor de Mina-Nagô Yemanjá - Pesquisa de campo ano 2016). Outra diz respeito à uma senhora católica que participa da Procissão do Senhor dos Passos há 20 anos que justifica se sentir muito feliz em participar, "apesar de ser cansativo e ter horas que dá vontade de parar, eu caminho com Jesus, porque ele precisa de cada um de nós nesse momento. Ele não pode caminhar sozinho" (A.S. Pesquisa de campo ano 2016).

Essas situações apontam para o entendimento de que mesmo que haja uma motivação individual para a mortificação, ela é pormenorizada no desejo de comunhão entre o fiel e Jesus, entre humano e divino que ao sacrificar o próprio corpo busca sentir o que é sentido pela divindade, sedimentando a crença de se estar sofrendo tal qual ela.

No que concerne às religiões afro-brasileiras, uma das suas principais características é o sacrifício, oferecido às divindades como dádiva e louvação. O sangue presente na vítima possui força vital que confere sacralidade aos objetos e as pessoas, por isso é muito comum em meio aos rituais sacrificiais se ouvir: "É 
vida pela vida!", uma afirmação pública de que o sacrifício realizado é uma consagração por um bem a ser recebido; tudo tem um fim e uma intenção. Na tradição católica, jejum, recolhimento e oração são meios de mortificação do corpo como preparação do espírito para rituais e celebrações religiosas ou para mudanças fundamentais da vida. Nas religiões afro-brasileiras seus adeptos têm interditos alimentares e que são diferentes do jejum, nestes interditos não há somente a abstinência de um alimento, mas o resguardo de se comer determinados tipos de comidas relacionadas aos arquétipos dos orixás.

Na Sexta-feira Santa, além dos resguardos alimentares os afro-religiosos do Tambor de Mina costumam fazer banhos de cabeça, resguardo sexual e recolhimento, conforme explicou uma afro-religiosa entrevistada: "os filhos de santo ficam recolhidos desde a segunda feira-santa, e passam a maior parte do tempo, quietos e em silêncio, se preparando para os banhos de cabeça e para receberem os "contra-eguns" e poderem fazer a visita às sete igrejas" (S.V. Integrante do Terreiro Mina-Nagô Ogum Rompe Mato, Pesquisa de campo ano 2017) Esses cuidados, ainda segundo esta entrevistada, "é a maneira de se mortificar e se proteger nesse tempo perigoso e de vazio, não somente porque os orixás desceram ao "orum”, mas também porque Jesus está morrendo".

Atentando-se para as nuances da compreensão sobre a mortificação ritual das duas matrizes religiosas pesquisadas, percebe-se que apesar de possuírem significados e motivações diferentes, ambas têm o corpo como expressão e canal da relação com o divino, de modo que as mortificações manifestam a "devoção à Paixão", no qual o corpo do devoto recebe e responde aos apelos aplicados pelos rituais, desenvolvendo uma comunicação direta entre o imanente e o transcendente. Essa idéia, segundo Pereira (2001, p.187), é muito antiga e perdura até hoje no imaginário da Religiosidade popular. As mortificações são na verdade, a oferta de si, na busca de viver a plena comunhão com Jesus a quem ela é oferecida.

Nos rituais ocorridos em Belém, essa relação próxima entre fiel e divindade (o santo; a imagem) é visível no gesto de se fitar os olhos nas imagens e contemplando as expressões de sofrimento, os peregrinos/devotos expressam comoção em lágrimas. E mais forte ainda quando nas igrejas visitadas, estes se põem a contemplar a imagem de Jesus morto e tocando-a imprimem no rosto a expressão de lamento e dor pela morte de alguém muito próximo.

As religiões sempre estiveram em busca de dar significações ao evento 'morte' e na maioria delas o sentido está ligado ao perigo que ela causa ou pode causar, seja no indivíduo ou na organização social, por estar relacionada ao mistério, à liminaridade, e consequentemente ao medo. Na tessitura de compreensões de como lidar com a morte e o morrer, Rodrigues (1975) pondera que o trabalho social ligado à morte, como quando e o que se pode comer; onde e como tratar do corpo morto ou que morre; quem deverá temê-lo e quem vai chorá-lo; e quem e quando enterrá-lo "é função de cada cultura e expressa particularidades de sua própria cosmologia e estrutura social" (RODRIGUES 1975, p. 56).

Morin (1988, p. 194), ao falar sobre a morte na cultura cristã argumenta que esta religião está enraizada a esse evento, uma vez que "é determinada unicamente pela morte. Cristo irradia em torno da 


\section{Nos passos da paixão, o encontro de matrizes: \\ Catolicismo e afrorreligiosidade na sexta-feira santa de Belém}

morte: só existe para e pela morte, traz consigo a morte e vive da morte". Esses conteúdos essenciais da doutrina católica, compreendidos como o supremo sacrifício, possibilitou Jesus passar da morte para a vida.

Nas cosmovisões indígenas e africanas a compreensão de relação mútua entre vida e morte, espíritos ancestrais e humanos, coexistência dos mundos dos vivos e dos mortos e o encante de espírito, se convergem e se fundem. Nestas tradições, essas crenças se interligam pelas narrativas de morte, ligadas também ao sacrifício, ao sofrimento, ao desaparecimento do mundo físico ou ainda pela morte violenta. Em muitas cidades do Brasil, as representações simbólicas referentes à morte, foram tecidas com leituras e interações que introduziu elementos da cultura ibérica, na mesma proporção que assimilou elementos culturais dos indígenas e dos africanos.

Uma peregrina católica disse: "na morte de Jesus vemos o sentido da vida, por isso é sinal de respeito velar ele morto. Ele morreu por nós! É como se alguém da nossa família tivesse morrido" (N. P, Pesquisa de campo ano 2017). Os que participam destes rituais entendem que esse é um dia para vivenciar o luto, expressar sentimentos de pesar e manter a atitude de silêncio em memória a Jesus que está morto. Esse comportamento remete ao fato de que ele está no sepulcro e isto representa o vazio no qual se encontra o mundo, por isso é comum que nas igrejas e capelas, não diferente em muitos terreiros, as imagens dos santos, bem como os vultos de caboclos e orixás e os tambores, sejam cobertos para simbolizar resguardo, luto e respeito. Segundo Vergolino-Henry (1987, p. 65), nos terreiros, a Sexta-feira Santa "é um dia de retiro. O clima é de [...] contrição e quietude; os tambores estão cobertos e silentes".

Essas atitudes são mantidas para se abrir mão e se despojar de tudo que possa transparecer festa e alegria. Quer as igrejas e capelas, quer os terreiros ou a rua, se tornaram um espaço vazio e liminar devido o luto pela morte de um corpo ambíguo: tem poderes divinos, mas está morto como qualquer humano e ao mesmo tempo que está ausente, é presente. Brandão (1987) argumenta que o catolicismo popular oferece, a partir de uma ética religiosa, formas de viver e formas de morrer, igualmente ocorre produzindo modos de se pensar a vida e de se compreender a morte.

Em muitos lugares do Brasil a morte é tida como uma passagem de um mundo para outro, ora pela subida (para o Céu), ora pela descida (para o Inferno) onde as almas, por sua vez, não desaparecem. Assim sendo, o ato de acender vela, oferecer água ou pão é uma ação necessária uma vez que as almas podendo transitar entre dois mundos podem também ser capazes de amedrontar ou amparar os vivos. Segundo Brandão (1987) as almas podem existir em mais de um mundo (terrenal ou sobrenatural) e assumir qualidades duais (Boas e Más). Tornam-se liminares pelo fato de que "são vivas porque agem, são mortas porque não estão vivas" (Brandão, 1987, p.187), por isso a crença de ser necessário oferecer auxílio às almas se fortaleceu ainda mais na Sexta-feira Santa. Em Belém, as narrativas do catolicismo e das religiões afro colaboraram para a difusão dessa ideia, pois neste dia os católicos não somente lembram a morte e o sepultamento de Jesus, mas se resguardam do "estado de vazio" ao qual se encontra o mundo pelo fato de 
Jesus ter ido ao encontro das almas que esperam seu resgate, sendo necessário rezar para que elas não fiquem "vagando" e nem "purgando" a sua espera e sejam merecedoras de serem resgatadas.

Já os afro-religiosos, segundo Vergolino-Henry (1987), desde a quarta-feira de cinzas até o sábado santo, período liturgicamente chamado de Tempo da Quaresma, se resguardam devido a partida temporária dos orixás e demais entidades dos diferentes panteões para Aruanda e de lá retornando somente no "sábado de aleluia". Eles também procuram se resguardar das consequências que podem ocorrer devido a morte de Jesus e que para ela, é explicado na fala de um afro-religioso ao dizer que "esses dias nunca serão iguais aos demais por representarem os dias em que Jesus Cristo sofreu neste planeta" (VERGOLINO-HENRY 1987, p. 61). Para esta pesquisadora, a morte é também um tema muito evidente nos terreiros, em que "[...] todo um conjunto de elementos que nos mitos originais está direta e indiretamente associado à temática morte" sãos colocados em primeiro plano nas liturgias (VERGOLINO-HENRY 1987, p. 65).

Durante a realização dos rituais, a maioria dos católicos e dos afro-religiosos, pouco interagem, evitando conversas e fazendo prevalecer o silêncio e a descrição, pois tudo passa pela relação com o sacrifício e morte de Jesus. Essa dimensão individual no espaço de culto coletivo, a igreja por exemplo, se dá pelo fato de que os que nele adentram, o fazem para fortalecer sua comunhão com o divino. Segundo Vergolino-Henry (1987), a mesma dinâmica ocorre nos terreiros onde antes, durante e após o ritual, há pouco interação entre os membros, as conversas se dão em tom baixo e as trocas de olhares são discretas. Esse cuidado é devido as divindades estarem ausentes, "prologando [...] a desproteção entre os homens" (VERGOLINO-HENRY 1987, p. 62) e redobrando a atenção motivada na crença na existência de espíritos vagantes e eguns.

Esses espaços tidos como lugares sagrados e plenos de mistérios, nesse dia são compreendidos como espaços temidos e perigosos, uma vez que, ao mesmo tempo em que estão vazios de espíritos de luz, nesse caso Jesus e Oxalá. Também estão presentes almas benditas e vagantes, expressando os sentimentos ambíguos dos vivos em relação aos mortos: são ao mesmo tempo queridos e temidos. Brandão (1987) ressalta que a ambivalência dos vivos para com os mortos se dá porque estes, mesmo sendo mortos, são presentes e por isso mais que nos outros dias esses lugares inspiram cuidado, fazendo com que algumas pessoas saiam das igrejas de costas. E assim, as representações da morte, com interações, releituras e ressignificações oriundas das tradições africanas, indígenas e cristãs católicas foram sendo tecidas e solidificadas numa estrutura de convergências teológicas sincréticas.

Uma ponderação a ser feita é que não existe uma forma única ou fechada de participação nos rituais públicos realizados na Sexta-feira Santa em convergência com o drama da Paixão. As formas são diferentes de terreiro para terreiro e consideram, crenças, doutrinas, cosmovisões e teologia próprias de cada um destes terreiros afro-religiosos. Outra ponderação é que as observações aqui descritas têm como foco de diálogo com a pesquisa da antropóloga Anaiza Vergolino, os rituais externos, de fora dos terreiros. 


\section{CONSIDERAÇÕES FINAIS}

A título de conclusão sem esgotar a temática, vale apontar que numa aproximação com a pesquisa desta antropóloga, publicada com o título "A Semana Santa nos Terreiros: um Estudo do Sincretismo Religioso em Belém do Pará", o que foi dito sobre a assimilação do tempo litúrgico católico pela matriz afroreligiosa Tambor de Mina, suas diferentes compreensões e ressignificações, sem afastamento ou conflito com o catolicismo é e sempre será necessário se dizer, sem a preocupação de ser repetitivo, como a própria antropóloga argumentara em seu texto, ao referir-se que o sincretismo é um fenômeno profundo.

Após se justificar o retorno à um tema já debatido, ressalta-se que ainda há muito o que se dizer sobre a Sexta-feira Santa, seja sob o enfoque dos afro-religiosos seja a partir da análise dos católicos. O olhar aqui evidenciado, por exemplo, pousou nos afro-religiosos e nas suas reinterpretações do mito bíblico da Paixão, não se pôde dedicar tempo na observação de como os católicos leigos ou a cúpula da igreja interpretam a participação destes afro-religiosos numa procissão organizada pela igreja.

Destarte, a revisita a pesquisa da antropóloga Anaiza Vergolino, 30 anos depois, mais que uma atualização é uma complementação, uma vez que ela focou na temática do sincretismo dedicando tempo e estudo para observar, etnografar e entender as dinâmicas dos terreiros do Tambor de Mina que realizam rituais internos considerando o tempo litúrgico católico, desde a Quarta-feira de Cinzas (início da Quaresma) até o Domingo de Páscoa (final do tríduo Pascal e da Quaresma). E, no caso deste trabalho, o foco se deu na observação e análise dos rituais públicos, ou seja, externos, e ocorridos no recorte temporal da Sexta-feira Santa, organizados pelos católico e que contam com igual presença entre de afro-religiosos mineiros, que os reinterpretam a partir de suas perspectivas.

Tomando consciência de lacunas e possibilidades sobre esta temática, os apontamentos aqui descritos interpelam desdobramentos de investigação sobre como os grupos afro-religiosos que não integraram esta pesquisa interpretam, revivem e celebram a Paixão, dentre eles, os umbandistas. E ainda, como os candomblecistas que não acolhem o sincretismo, justapõem o mito da pureza nagô a essa devoção sincrética? Essas indagações, mais do que demonstrar fragilidades, apontam quão rica é a temática das interações afrocatólicas e que já sustentam questionamentos para pesquisas e análises no vasto campo da afro-religiosidade presente na Amazônia paraense.

\section{REFERÊNCIAS BIBLIOGRÁFICAS}

AVANCINI, Elsa Gonçalves. O sagrado na tradição africana e os cultos afro-brasileiros. In: SILVA, Gilberto Ferreira da; SANTOS, José Antônio dos; CARNEIRO, Luiz Carlos da Cunha (Org.). RS negro: cartografias sobre a produção do conhecimento. [recurso eletrônico] - Dados eletrônicos - 2. ed. rev. e ampl. Porto Alegre/RS: EDIPUCRS, 2010. p.

BÍBLIA SAGRADA: Edição Pastoral. São Paulo: Paulus, 2010. 


\section{Nos passos da paixão, o encontro de matrizes: \\ Catolicismo e afrorreligiosidade na sexta-feira santa de Belém}

BOFF, Leonardo. Igreja: carisma e poder. Petrópolis-RJ: Vozes, 1981.

BRANDÃO, Carlos Rodrigues. Sacerdotes de viola. Petrópolis: Vozes, 1981.

BRANDÃO, Carlos Rodrigues. Os deuses do povo: um estudo sobre a religião popular. São Paulo: Editora Brasiliense, 1987.

CARDOSO DE OLIVEIRA, Roberto. O trabalho do antropólogo. SP: Unesp, 2000.

CARNEIRO, Sandra Maria Corrêa de Sá. Novas peregrinações brasileiras e suas interfaces com o Turismo. Ciencias Sociales y Religión/Ciências Sociais e Religião, Porto Alegre, ano 6, n. 6, p.71-100, outubro de 2004.

COELHO, Maria Filomena. Viagem e peregrinação na antiguidade tardia: narrativa do conhecido. Projeto História $\mathrm{n}^{\mathrm{o}}$ 42. junho de 2011. Disponível em: http://revistas.pucsp.br/index.php/ revph/article/viewFile/7994/5870.

DWORAK, Rzysztof. A peregrinação à Lapa do Bom Jesus: um percurso desafiante. Revista Lusófona de Ciência das Religiões - , nº 20, 2017.

ELIADE, Mircea. O sagrado e o profano: a essência da religião. São Paulo: Martins Fontes. 1992.

FERNANDES. Rubem César. Os cavaleiros do Bom Jesus: uma introdução às religiões populares. São Paulo: Editora Brasiliense, 1982.

FERRARO, Benedito. Cristologia em tempos de ídolos e sacrifícios. São Paulo: Paulinas, 1993.

FERRETI, Mundicarmo. Religião e sociedade: religiões de matriz africana no Brasil, um caso de polícia. JORNADA NACIONAL DE POLÍTICAS PÚBLICAS, 3. 2007, São Luís. Anais [...]. UFMA, 2007.

FRANÇA, Susani Silveira Lemos; NASCIMENTO, Renata Cristina de Sousa; LIMA, Marcelo Pereira. Peregrinos e peregrinações na Idade Média. - Petrópolis, RJ: Vozes, 2017.

GIL FILHO, Sylvio Fausto. Espaço sagrado: estudos em geografia da religião. Curitiba: Editora IBPEX, 2008.

GEERTZ, Clifford. A interpretação das culturas. 13ª reimpr. - Rio de Janeiro: LTC, 2008.

GUMIEIRO, Fábio. As ordens religiosas e a construção sócio-política no Brasil. Tuiuti: Ciência e Cultura, Curitiba, n. 46, p. 63-78, 2013.

HURBERT, Stefan. Manjar dos deuses: as oferendas nas religiões afro-brasileiras. Primeiros Estudos, n. 1, São Paulo, 2011.

JANSEN, Karine. A dramaturgia das paixões de Cristo em Belém do Pará. Revista Ensaio Geral, Belém, v.1, n.1, jan-jun 2009.

JURKEVICS, Vera Irene. As irmandades negras: "lócus" de religiosidade popular. Revista Tecnologia e Sociedade. Curitiba, n. 2, $1^{\circ}$ semestre de 2006. 
LUCA, Taissa Tavernard de. Tem branco na Guma: a nobreza europeia montou corte na encantaria mineira. 2010, Tese (Doutorado). Programa de Pós-Graduação em Ciências Sociais, Universidade Federal do Pará, 2010.

MALINOWSKI, Bronislaw. Argonautas do Pacífico Ocidental. São Paulo: Editora Abril, 1984.

MAUÉS, R. Heraldo. Padres, pajés, santos e festas: catolicismo popular e controle eclesiástico. Belém: Cejup, 1995.

MAUSS, Marcel; HUBERT, Henri. Sobre o sacrifício. São Paulo: COSAC NAYF, 2013.

MATTOSO, Kátia Q. Bahia, século XIX, uma província do Império. Rio de Janeiro: Nova Fronteira, 1992.

MESLIN, Michel. Fundamentos de antropologia religiosa: a experiência humana do divino. Vozes, SP. 2014.

MORIN, Edgar. O homem e a morte. Lisboa: Publicações Europa-América. 2. ed. 1988.

PEREIRA, José Carlos. A eficácia simbólica do sacrifício: estudos das devoções populares. São Paulo, Arte e Ciência, 2001.

PEREIRA, José Carlos. A linguagem do corpo na devoção popular do catolicismo. REVER: Revista de Estudos da Religião, nº 3, p. 67-98, 2003.

RAMOS, José Maria Guimarães. A aparição da imagem de Nossa Senhora de Nazaré em Belém do Pará; análise da manifestação do sagrado na Amazônia. 2015, Dissertação (Mestrado) Ciências da Religião). Universidade do Estado do Pará/UEPA. Belém, 2015.

RIBEIRO, René. Cultos afro-brasileiros do Recife. Recife: IJNPS, 1978.

RIES, J. Symbole, mythe et rite. Constantes du sacré, Paris: Cerf. 2012.

RODRIGUES, José Carlos. O tabu do corpo. Rio de Janeiro: Edições Achiamé Ltda., 1975.

ROSENDAHL, Zeny. Tempo e temporalidade, espaço e espacialidade: a temporalização do espaço sagrado. Revista Espaço e Cultura. Rio de Janeiro: Eduerj. n. 35. Jan./jun., 2002.

SANCHIS, Pierre. Peregrinação e romaria: um lugar para o turismo religioso. Revista Ciências Sociais e Religião, Porto Alegre, ano 8, n. 8, p. 85-97, 2006.

SANTOS, Glauber Eduardo de Oliveira. Importância das peregrinações para o turismo mundial. Turismo em Análise, São Paulo, nov., p. 38-44, 2000.

SANTOS, Rosalira Oliveira dos; GONÇALVES, Antonio Giovanni Boaes. A natureza e seus significados entre adeptos das religiões afrobrasileiras. Revista Brasileira de História das Religiões. Maringá (PR) v. III, n.9, jan/2011.

SOUZA, Laura de Mello e. O diabo na terra de Santa Cruz. São Paulo: Cia. das Letras, 1986.

SOUZA, Marina de Mello e. Catolicismo negro no Brasil: santos e minkisi, uma reflexão sobre miscigenação cultural. Afro-Ásia, Bahia, 28, p. 125-146 2002. 


\section{Catolicismo e afrorreligiosidade na sexta-feira santa de Belém}

STEIL, Carlos Alberto. O sertão das romarias: um estudo antropológico sobre o Santuário de Bom Jesus da Lapa - Bahia. Rio de Janeiro: Editora Vozes, 1996.

TERRIN, Aldo Natale. Antropologia e horizontes do sagrado: culturas e religiões. São Paulo: Paulus, 2004.

VERGOLINO-HENRY. Anaíza; FIGUEIREDO, Arthur Napoleão. A presença africana na Amazônia colonial: uma notícia histórica. Belém: Arquivo Público do Pará, 1990.

VERGOLINO-HENRY. Anaíza, A semana santa nos terreiros: um estudo de sincretismo religioso em Belém do Pará". In: Religião e Sociedade. Rio de Janeiro, volume 8 ISER, 1987.

ZUMTHOR, Paul. La medida del mundo. Madrid: Cátedra, 1994.

Texto recebido em: 10/11/2020

Texto aprovado em: 21/11/2020 